\title{
4. NEOGENE TECTONIC EVOLUTION OF THE CELEBES-SULU BASINS: NEW INSIGHTS FROM LEG 124 DRILLING1
}

\author{
Claude Rangin ${ }^{2}$ and Eli A. Silver ${ }^{3}$
}

\begin{abstract}
The Neogene tectonic evolution of the Celebes-Sulu basins is discussed on the basis of representative seismic profiles, published industrial wells, and Leg 124 drilling results. The study is also based on geological data collected all around the margins of these basins. A synthetic cross section was built from the South China Sea to Sulawesi, and correlation of the major magmatic and tectonic events was attempted. We suggest that these basins and their margins (Celebes-Sulu block) collided with the rifted margin of China (Reed Bank) around $16 \mathrm{Ma}$. A main event of submarine pyroclastic emplacement coincided with this collision. The Sulu Basin probably opened in a back-arc position for the Cagayan volcanic arc in early Miocene time. Incipient closing of the Sulu and Celebes basins, still presently active, is documented within their sedimentary cover.
\end{abstract}

\section{INTRODUCTION}

The marginal basins of the western Pacific region have received previous attention from deep-sea drilling, but until now southeast Asian basins not clearly related to back-arc extensional processes have been largely ignored. The Sulu, Celebes, and Banda seas are located at the junction of three converging major plates (Eurasia, Philippine Sea, and Australia, Fig. 1). The depositional history of these basins can provide important constraints on their tectonic evolution (opening and presently active closing processes). Drilling these Southeast Asian basins has provided new data on the nature and age of their basement and consequently on their origin.

This paper integrates the drilling results of Leg 124 with geological data collected around the margins of these basins to more fully analyze their depositional and tectonic evolution. We discuss the evolution of the Sulu and Celebes basins along a cross section from Palawan $(\mathrm{P})$ to the north arm of Sulawesi (NS in Figs. 2 and 3). Correlation of stratigraphic data is made using the Berggren et al., (1985) time scale. We examine the timing of events, including opening of the Sulu Sea, timing of Cagayan volcanic activity, collision of Palawan and surrounding areas, and major pulses of uplift and initiation of trenches. We use drill sites 767 to 771 , published information on industrial wells, seismic data, and land observations to construct the section. A major purpose of drilling Leg 124 was to use the basin stratigraphy to interpret the regional tectonic history. This paper focuses on the Neogene.

\section{TECTONIC FRAMEWORK OF THE CELEBES-SULU BASINS}

\section{Regional Tectonic Setting of the Basins in Southeast Asia}

Various crustal fragments occur within the collision zone of the three major plates (EU-PSP-AUS), depicted in Fig. 1. The Sulu and Banda blocks, including small oceanic basins

\footnotetext{
${ }^{1}$ Silver E. A., Rangin, C., et al., 1991. Proc. ODP, Sci. Results, 124: College Station TX. (Ocean Drilling Program).

2 Département de Géotectonique, URA 1315 CNRS, Université Pierre et Marie Curie, 4 Pace Jussieu, 75252 Paris Cedex, France.

${ }^{3}$ Earth Sciences Board and Institute for Marine sciences, University of California, Santa Cruz, CA 95064 U.S.A.
}

(Sulu, Celebes or Banda) have been interpreted either as exotic blocks or fragments of the adjacent major plates.

The island of Sulawesi appears to be a major suture zone along which a large oceanic basin (probably the Neotethys) was subducted (Hamilton, 1979; Silver et al., 1983a, 1983b). Along this suture zone, the Banda and Celebes-Sulu blocks were welded together in middle Miocene time (Kundig, 1956). The middle Miocene is also the time for the collision of the northern margin of the Celebes-Sulu block with the rifted continental margin of the South China Sea (Palawan, P; Reed-Bank, RB; Dangerous-Grounds, DG, areas). Thus, the northwestern and southeastern boundaries of the Celebes-Sulu block were welded in the middle Miocene to the rifted China margin (Palawan) and the Banda block, respectively. The southern boundary of the Banda block collided with Australia in the Pliocene (Audley-Charles, 1968; Hamilton, 1979).

The Celebes-Sulu block is fringed on the east by the transpressive Philippine Mobile Belt. The volcanic-arc terranes forming the major part of this belt (Philippine arc), originated as part of the Philippine Sea Plate (Jolivet et al., 1989; Rangin and Pubellier, 1990).

\section{The Tectonic Boundaries of the Celebes-Sulu Block}

The tectonic boundary between the rifted continental margin of China and Cagayan Ridge is difficult to trace because it is blanketed by Neogene sediments on both sides of Palawan Island. This suture zone was thought by Holloway (1982) to be represented by the Palawan Trench. Hinz et al. (1985) suggested the presence of a southward-dipping slab of continental crust below Palawan, reaching far into the Sulu Sea. According to this interpretation, based on analysis of multichannel seismic data, the Palawan accretionary prism represents the deformed and imbricated continental-slope sediments of the rifted Eurasian margin. Based on the work of Hinz et al. (1985), the Palawan trough is a foreland thrust zone for the Cagayan-Reed Bank collision (Fig. 3).

This collision zone can be traced westward into Sabah (Rangin et al., 1990b), where late Oligocene-Miocene islandarc assemblages of rocks overthrust the clastic sequence of the Crocker Range (CR in Fig. 2). These clastic sediments interfinger westward with the shallow-water deposits of the Miri Platform (MP in Fig. 2), which can be correlated with the offshore Dangerous Grounds (DG in Fig. 2) platform. In southern Sabah this suture zone is offset by important sinistral 


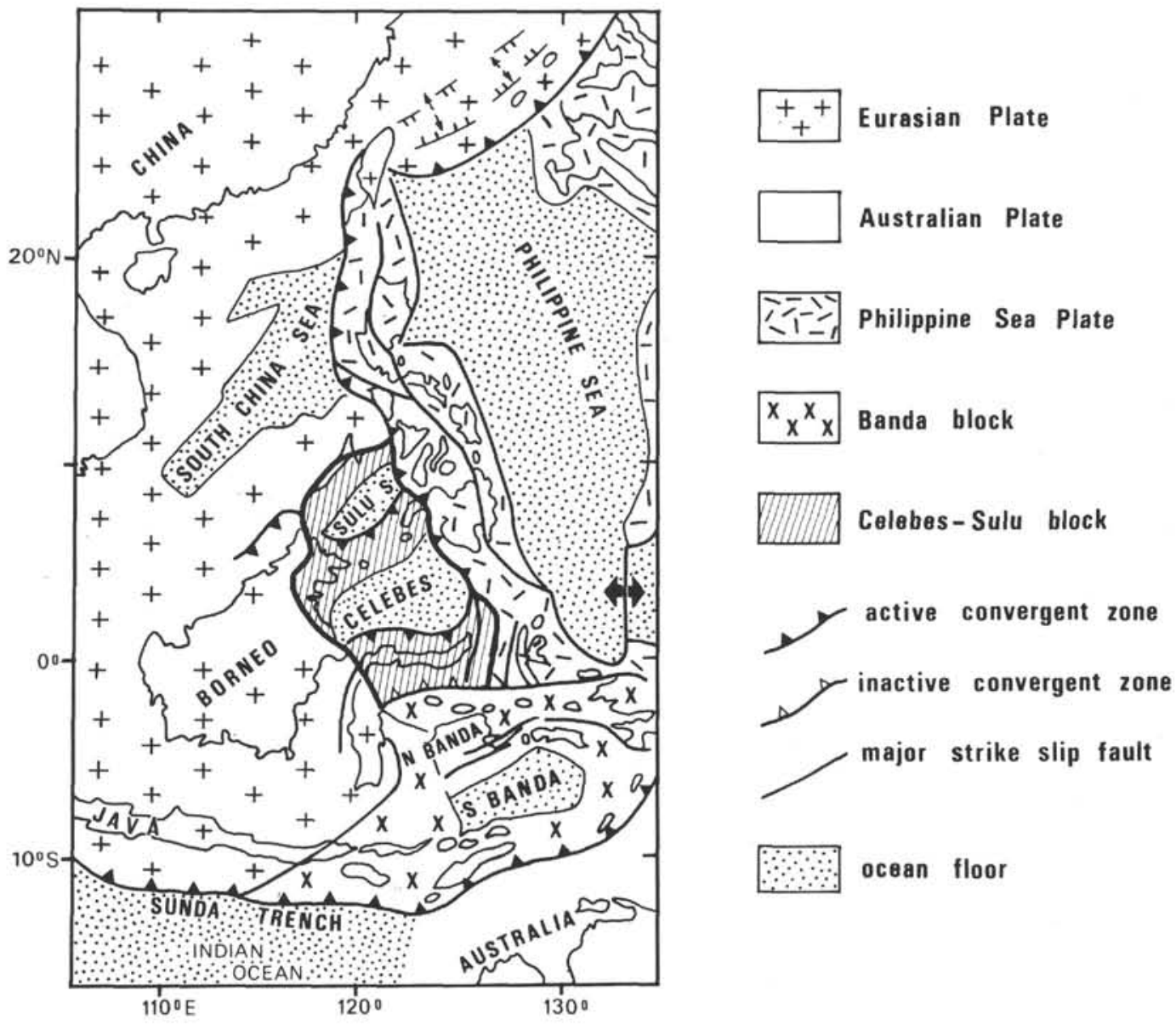

Figure 1. Location of the Celebes-Sulu block within the tectonic framework of surrounding major plates in Southeast Asia.

strike-slip faults that may connect (Rangin et al., 1990b) with the Palu Fault of Sulawesi (Hamilton, 1979).

The eastern boundary of the Celebes-Sulu block is presently outlined by the Negros (NT) and Cotabato trenches (CT), bounding the west side of the Philippine Mobile Belt (Philippine arc in Fig. 2). This belt is composed mainly of Cretaceous-Paleogene calc-alkalic volcanic sequences forming the Philippine island arc that fringes the Philippine Basin on its western side (Fig. 1). Some fragments of the Eurasian Plate or the Celebes-Sulu block are present along the western edge of the Philippine Mobile Belt. These fragments were incorporated into the Philippine arc during its collision with the Celebes-Sulu block in Miocene time. Fragments of the rifted Chinese continental margin were recognized in Mindoro, Philippines (Holloway, 1982; Sarewitz and Karig, 1986; Marchadier and Rangin, 1990). Fragments of the Cagayan (CR north of Sulu Basin) and Sulu ridges (SR) were identified in the Western Antique Range of Panay Island, Philippines.

\section{The Southern Boundary: The Sulawesi Collision Zone}

The presently active Sangihe arc (SA in Fig. 2) begins at the northern tip of the north arm of Sulawesi (NS) and extends northward to near Mindanao (M). This arc lies above the northwestward-dipping subducted slab of the Molucca Sea Plate (located just to the east of the Sangihe arc), which was at least $1000 \mathrm{~km}$ wide before subduction (Silver and Moore, 1978).
Proceeding west along the north arm of Sulawesi (NS), active volcanism dies out rapidly, and the basement of the arc is exposed on its western end. In eastern Sulawesi the fore arc has collided with the Sula block (Fig. 2), a detached piece of Australia (Silver et al., 1983a,b).

\section{A CROSS SECTION OF THE CELEBES-SULU BLOCK}

A cross section from Reed Bank to Central Sulawesi (Figs. 2 and 3) reveals the Neogene internal deformations of the Celebes-Sulu block. This transect is based on published refraction, multichannel seismic (MCS) and dredging data, as well as land geology observations made along emerged land separating the Southeast Asian basins (Palawan Island, P, the Sulu archipelago, SR, and the north arm of Sulawesi, NS). A schematic section is shown in Figure 3.

\section{From Reed Bank to Cagayan Ridge}

Between Reed Bank (RB) and Cagayan Ridge (CR north of Sulu Basin) lies a complex deformed zone (Fig. 2). This collision complex extends southwestward to Sabah (northeast Borneo), where it is presently overthrusting northward onto the Dangerous Grounds platform (DG), a lateral equivalent of Reed Bank (RB) (Hinz et al., 1989; Rangin, 1989). The timing of this deformation is documented by industrial walls drilled on both the inner and outer walls of the Palawan Trough and in the Northwest Sulu Basin. Deformation is 


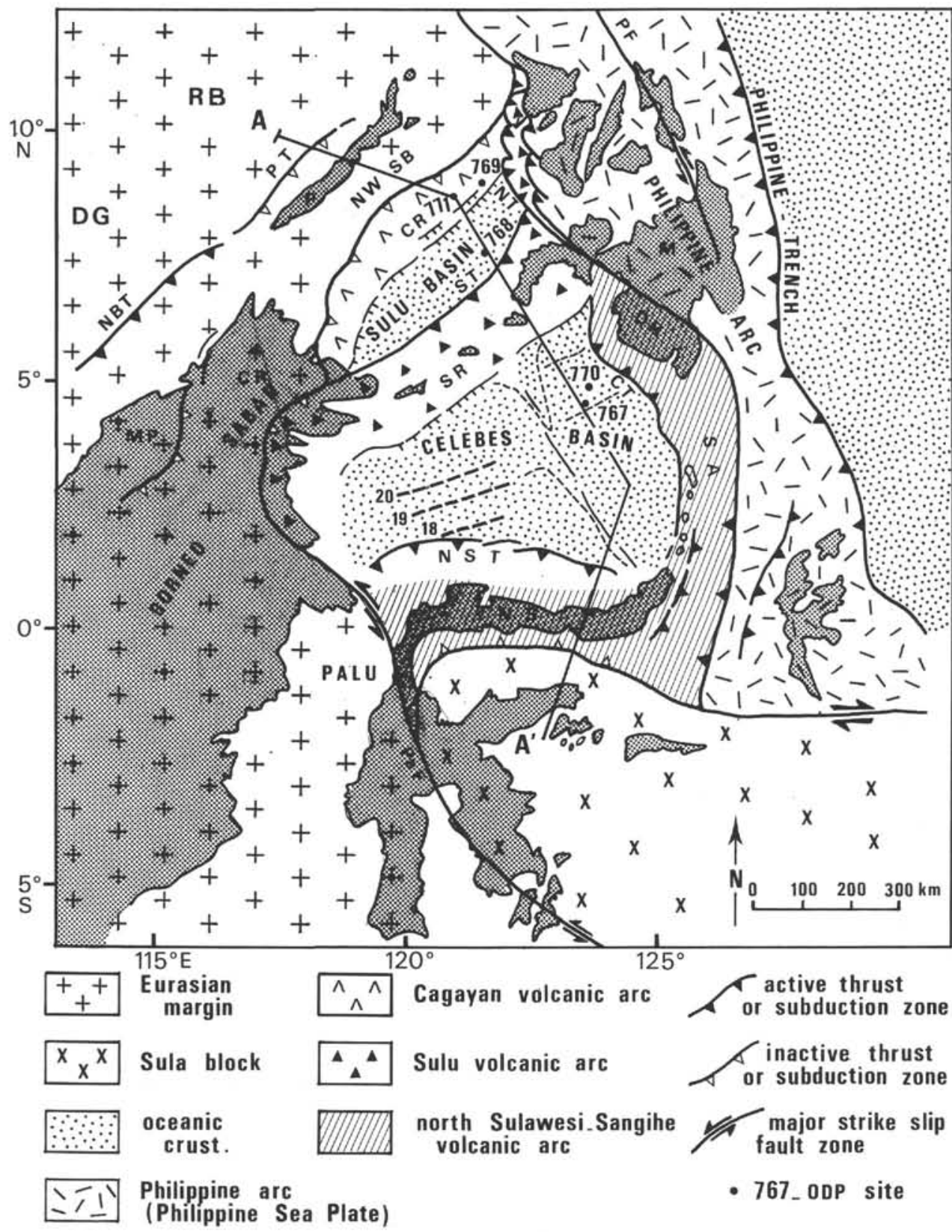

Figure 2. Structural sketch map of the Celebes Sulu block. CR, Cagayan Ridge; CT, Cotabato Trench; DG, Dangerous Grounds; DR, Daguma Range; MP, Miri Platform; NBT, north Borneo Trench; NS, North Sulawesi; NST, North Sulawesi Trench; NT, Negros Trench; NWSB, Northwest Sulu Basin; P, Palawan; PaF, Palu Fault; PF, Philippine Fault; PT, Palawan Trench; RB, Reed Bank; SA, Sangihe Arc; SR, Sulu Ridge; ST, Sulu Trench. Trace of section on Figure 3 is shown.

also recorded in the Reed Bank platform. Deformation has been inactive in Palawan and the Northwest Sulu Basin area since early-middle Miocene time, and a thick undisturbed package of Neogene sediments covers the folded sequences unconformably.

\section{Depositional History of Reed Bank}

In the Reed Bank-Dangerous Grounds province, the oldest rocks encountered by dredging (Kudrass et al., 1990) and drilling are Upper Triassic deltaic sandstones with siliceous shales, gabbros, diorites and dacites. In Reed Bank, transgression occurred during late Paleocene time with deposition of thin, shallow-water limestones during an active episode of block faulting and gradual subsidence. This episode is interpreted as the onset of rifting of the South China Sea (Hinz and Schluter, 1985). Crustal extension continued during early and middle Eocene time with deposition of deep-water marine shales (Fricaud, 1984; Letouzey et al., 1988). Rifting proceeded in late Eocene to early Oligocene time with formation of large fault blocks that are covered disconformably by upper Oligocene to lower Miocene platform carbonates. Eastward, flexure of this platform occurred at the lower/middle Miocene boundary and a new episode of faulting affected the carbonates. Simultaneously, increasing subsidence rates and clastic sedimentation proceeding from north to south along the Palawan trough 


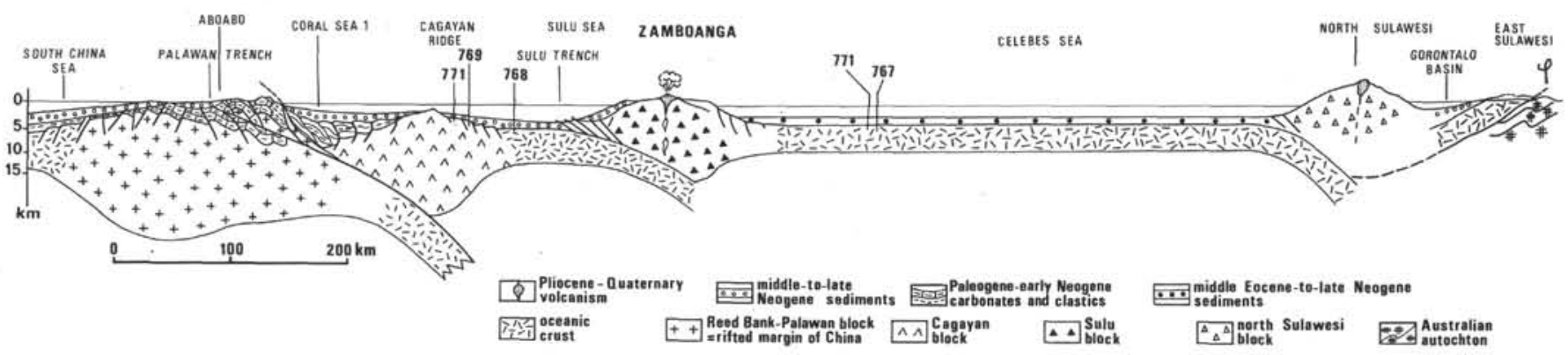

Figure 3. Simplified cross section of the Celebes-Sulu block.

(Fricaud, 1984) flooded the carbonate platform. Conglomerates of reworked carbonates, cherts, and ultramafic rocks indicate uplift and erosion of north Palawan at that time.

\section{Depositional and Tectonic History of the Palawan-Northwest Sulu Basin}

Hinz et al. (1985) demonstrated that the top of the upper Oligocene-lower Miocene carbonates of Reed Bank-Dangerous Grounds extends under the Palawan wedge. Consequently, the Palawan Trench was formed by an elastic downwarp of the crust as a result of isostatic compensation for the thick overthrust deformed wedge. In this wedge only the Neogene deformation is well documented and the deformation front is covered unconformably by middle Miocene sediments (Holloway, 1982; Fricaud, 1984; Hinz et al., 1985). Similarly, both the southernmost thrust slices of this accretionary wedge and Cagayan Ridge are covered unconformably by middle Miocene sediments in the Northwest Sulu Basin (Beddoes, 1976; Mascle and Biscarrat, 1978; Rangin, 1989). On both sides of Palawan Island the same regional unconformity was identified on seismic profiles (Hinz et al., 1985). It forms the top of the deformed, very thick rock complex underlying the western and eastern slopes of central and south Palawan and the Northwest Sulu Basin.

Industrial wells drilled on both sides of Palawan Island revealed an early middle Miocene age for this unconformity. The Coral Sea 1 drill hole reported by Beddoes (1976) in the Northwest Sulu Basin (Fig. 4) dated the unconformity at the boundary of Zones N8-N9 (15.2 Ma on the scale of Berggren et al., 1985). On the South China Sea side, at the toe of the wedge, the Aboabo AXl well penetrated $3773 \mathrm{~m}$ into thrusted sediment slices with alternating Eocene and middle Miocene strata (Fig. 4). The overlying regional unconformity can be traced along the toe of the wedge (wells Murex 1, Kamonga 1, SW Palawan 1, Likas 1) and was dated early middle Miocene (15-14 Ma, Hinz et al., 1985).

The accretionary wedge of the Palawan Ridge is composed of a complex pile of thrust slices with evident polyphase deformation (Fig. 5). Ophiolites are imbricated with a clastic sequence of late Paleocene to early middle Miocene age (Mitchell et al., 1986; Raschka et al., 1985; Wolfart et al., 1986; Letouzey et al., 1988). Harzburgite bodies sliced with lower to possibly middle Eocene pelagic sediments and pillow basalts (Bacungan Group; United Nations, 1985) are thrust northwestward onto the limestone and clastic sequences (Fig. 5). These ophiolites may have originated in the northwest Sulu Basin where a relict fragment of oceanic crust was suspected by Hinz and Block (1990). A similar tectonic relationship was observed on Mindoro Island, Philippines, where ultramafics and middle Oligocene pillow basalts were thrust between the Palawan shelf and an island arc during the early middle Miocene (Zone NN5) (Rangin et al., 1985). On Palawan as on
Mindoro, these lower Tertiary ophiolites might represent remnant pieces of the proto-South China Sea.

The tectonic relationships between Cagayan Ridge and the folded lower sequence of the Northwest Sulu Basin are obscured by the middle Miocene unconformity (Fig. 6). However a rapid change of crustal layering was documented along the western slope of Cagayan Ridge by Murauchi et al. (1973) based on refraction data.

All these data suggest that a major suture zone exists in the Northwest Sulu Basin that marks the collision between Cagayan Ridge and the rifted margin of the South China Sea (Reed Bank). Obduction of ophiolites occurred before collision that ceased in early-middle Miocene time.

\section{From Cagayan Ridge to Sulu Ridge}

\section{Cagayan Ridge}

Cagayan Ridge divides the Sulu Sea into two sub-basins. It is a prominent east-northeast-trending submerged ridge characterized by a relatively smooth northwest slope and a steep southeast slope marked by normal faults. The northern section of the ridge is capped by numerous reef islands, and 400 $\mathrm{m}$ of reefal deposits was drilled on one island. The southern end of this ridge was drilled south of Sulu Island and revealed the presence of a thick sequence of andesites, basaltic flows, and pyroclastics alternating with lower and lower middle Miocene shallow-marine to brackish clastic sediments (reported in Letouzey et al., 1988). K/Ar ages (Kudrass et al., 1990) were obtained from dredged rocks from two localities along that ridge. Dates obtained from rocks along the eastern ridge flank are not older than $20 \mathrm{Ma}$, but for another locality much older ages are reported.

However, this dredge site is located close to the axis of a major canyon flowing southeastward from southern Panay Island, where the pre-Neogene volcanic rocks of the Philippine arc are exposed. Consequently we urge caution on the interpretation of these dredged data. We think that only the rocks of the first locality clearly originated from Cagayan Ridge. These dates agree well with the 14.7-Ma age obtained by Kuddrass et al. (1987) from volcanics drilled at Sites 769 and 771. Cagayan Ridge may extend to the Sandakan area in Sabah, where upper Oligocene (Zone NP25) sediments are mixed with tuffs, massive andesitic flows, and microbreccias (Rangin et al., 1990a). If the nannofossils are not reworked, this age would be the oldest available for the Cagayan Ridge volcanic activity.

\section{ODP drilling on Cagayan Ridge}

The structure of the southeastern flank of Cagayan Ridge, where Leg 124 holes were drilled, is quite simple as indicated by seismic and SeaBeam data (Mascle and Biscarrat, 1978; Hinz et al., 1989; Rangin, Silver, von Breymann, et al., 1990). 


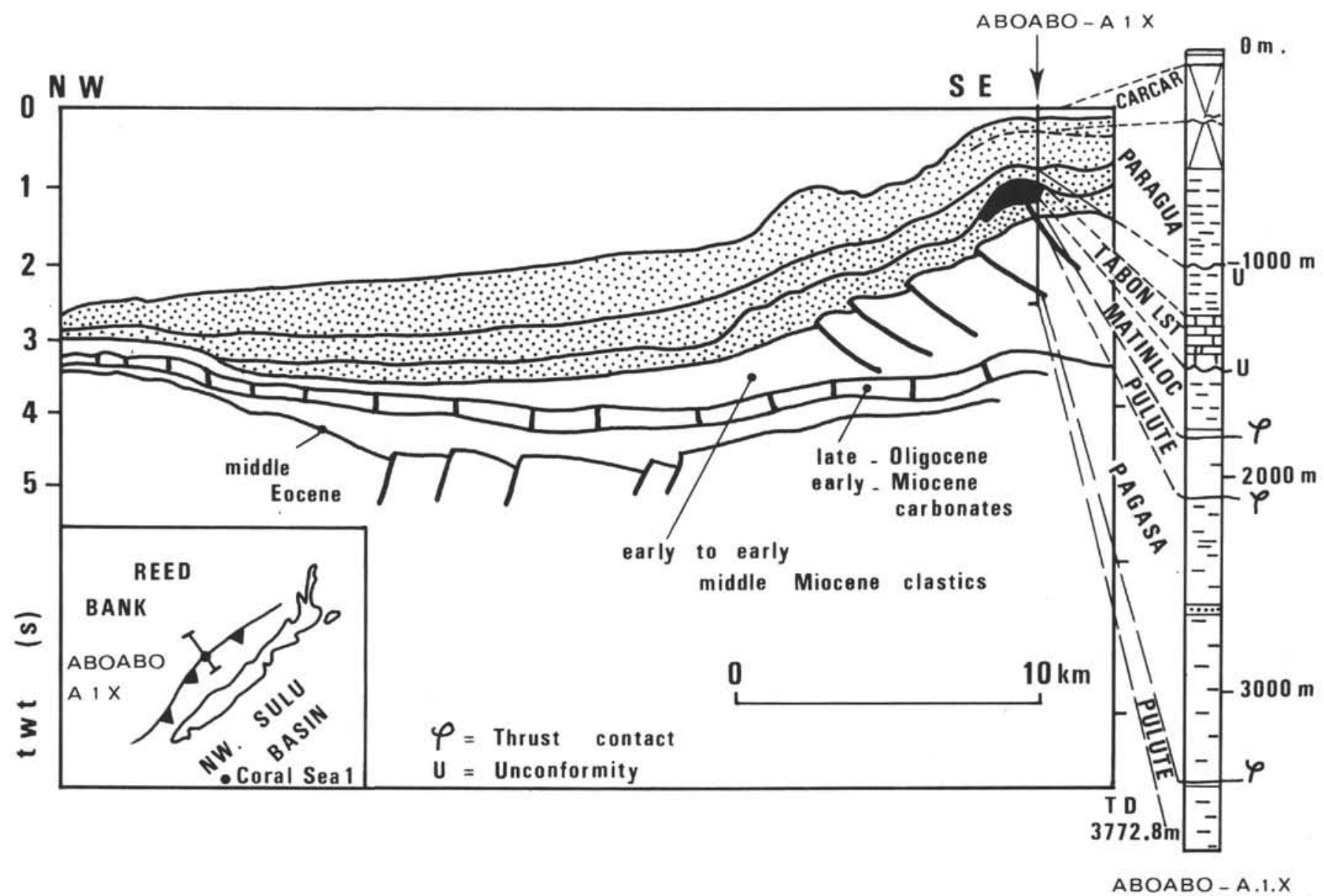

Figure 4. Seismic interpretation of the Palawan trough. The Aboabo A $1 \mathrm{X}$ well is correlated with seismic reflectors. Post-collision undeformed sediments are shown with dots (slightly modified from Hinz et al., 1985).

NNW

REED BANK
PALAWAN

TROUGH
PALAWAN RIDGE

Bacungan group.

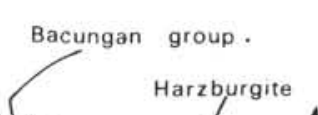

ESE

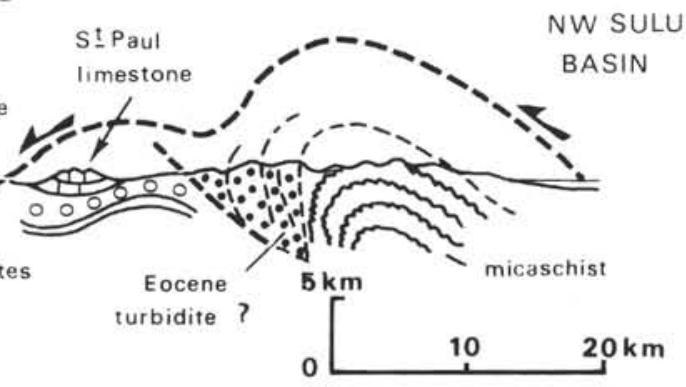

\section{limestone}

L. Eocene

L. Miocene M.L. Imbricated

Figure 5. Cross section of the Palawan Ridge (slightly modified from United Nations, 1985).

A few seismic profiles cross the ridge and show clearly tilted blocks (Fig. 7). Site 771 was drilled on a large plateau blanketed by a layer of sediments 0.3 to $0.5 \mathrm{~s}$ thick. These sediments overlie a flat, highly reflective layer, which in turn covers tilted blocks of the acoustic basement (Fig. 7). Drilling showed the intermediate layer to be volcanic. The hole was drilled to $100 \mathrm{~m}$ below seafloor (mbsf) before the first spot core was taken and continuous rotary coring began at $145 \mathrm{mbsf}$. The dominant volcaniclastic unit is represented by massive and structureless lapillistone. These pyroclastic deposits suggest proximity to a volcanic vent or set of vents. The oldest layer of mudstone intercalated into the tuffs was dated at the upper part of Zone NN3 (17.8 Ma), and the youngest pyroclastics were dated at Zone NN5. Hemipelagic sediments overlying the tuffs were also dated at Zone NN5, suggesting that deposition of pyroclastics, if they were not reworked, stopped during the period covered by Zone NN5.

Site 769 was drilled on the southeastern flank of Cagayan Ridge (Fig. 7). Brown claystone of early Miocene (radiolarian) age (probable Stichocorys wolffii Zone) lies above the volcaniclastics. Pelagic sedimentation is indicated by a low silt content and the presence of manganese micronodules. 

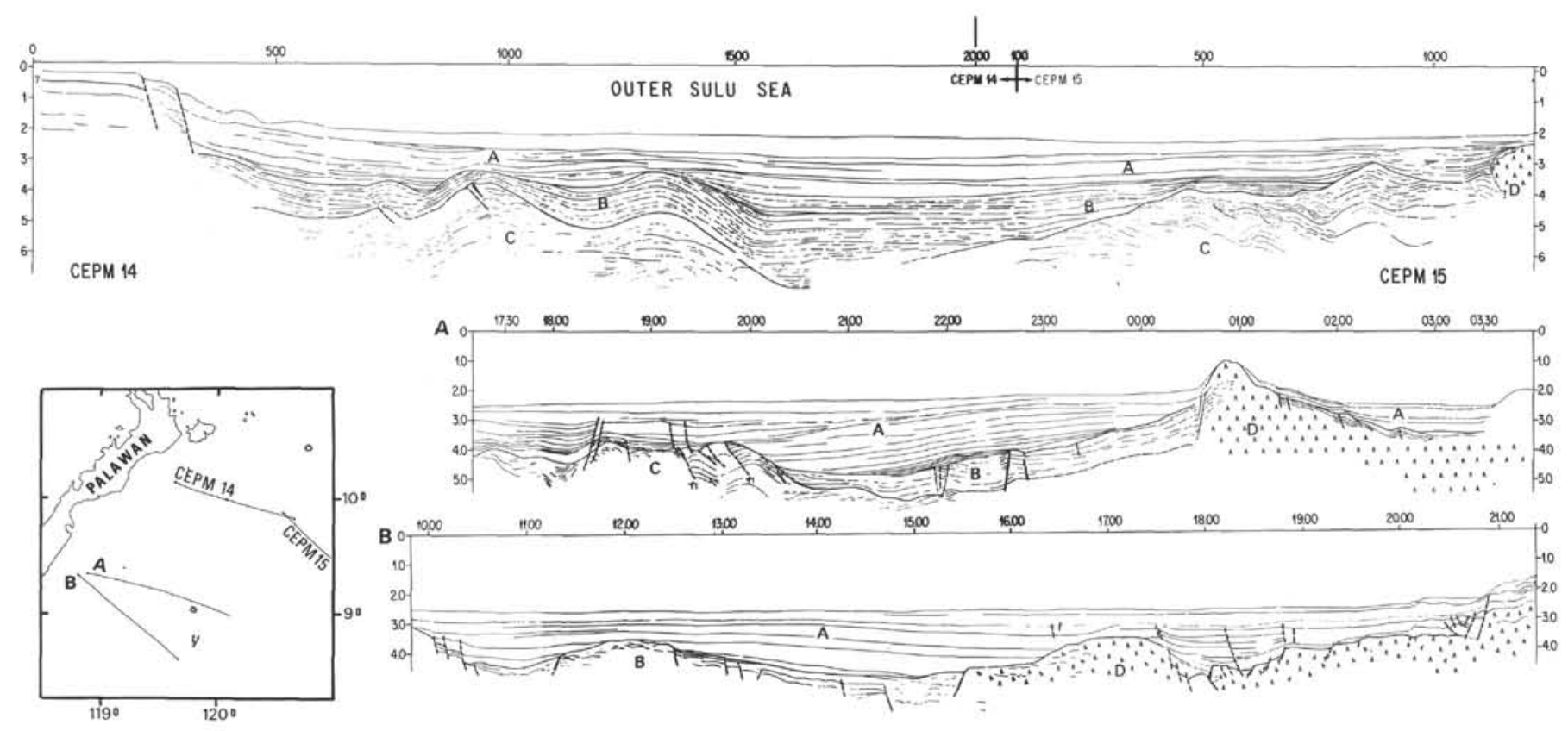

Figure 6. Line drawing of selected profiles in the northwestern Sulu Basin (from Rangin, 1989).

Deposition of pyroclastics therefore stopped before 17.2 Ma. The underlying volcaniclastics consist of massive, unstratified, dark-green coarse tuffs and lapillistone of andesitic to basaltic composition with no intermixed or interbedded sedimentary material.

The duration of this large pyroclastic event could not be determined at Sites 769 and 771 because the base of the pyroclastic unit was not reached. On seismic profile SO49-05 (Fig. 7), this pyroclastic layer was interpreted by Hinz et al. (1988) as unconformably covering large tilted blocks, the nature of which remains unknown. At Site $768,200 \mathrm{~m}$ of rhyolitic pyroclastic material is enclosed within a brown pelagic mudstone overlying the Sulu Sea basement.

Correlations by radiolarian dating of the brown mudstones, and the magnetostratigraphy of the pyroclastics, suggest that the volcaniclastics were deposited between 18.6 and $16.4 \mathrm{Ma}$. If the correlation between the pyroclastics of Cagayan Ridge and the Southeastern Sulu Basin is correct, this explosive volcanic activity would not have lasted more than $2 \mathrm{~m}$.y. The calc-alkalic composition of the pyroclastics suggests an arc origin (Rangin, Silver, von Breymann, et al., 1990). The nature of the Cagayan Ridge basement remains unresolved. $\mathrm{K} / \mathrm{Ar}$ dating of basaltic and andesitic fragments engulfed within the pyroclastics yielded ages of $20.6 \mathrm{Ma}$ (Section 124-769C-7R-1) and 19.8 Ma (Section 124-769C-9R-3) (Bellon, written commun., 1990). These dates agree well with the ages obtained from Cagayan-like rocks on Panay (Bellon and Rangin, this volume).

Cagayan Ridge appears to have formed by two successive episodes of volcanism. The first is an episode of latest Oligocene-early Miocene age marked by eruptions of andesites and basalts. The second episode was marked by emplacement of large volumes of pyroclastics, from 19 to $16 \mathrm{Ma}$.

\section{Nature and Age of the Sulu Seafloor}

The Southeast Sulu Basin is characterized by a relatively flat basement overlain by a thin cover of sediments. Seismic profiles (Hinz and Block, 1990) show the presence of small, asymmetrical, southeast-facing asperities that can be interpreted as small tilted blocks. The magnetic anomalies are poor but are tentatively identified as being 30 to $10 \mathrm{Ma}$ (Roeser, this volume) with an asymmetrical pattern. This interpretation of the magnetic anomalies implies a very slow spreading rate $(0.6$ $\mathrm{cm} / \mathrm{y}$.). If the relationship between roughness of the oceanic basement and spreading rates known in steady-state oceanic ridges can be applied to marginal basins, the flatness of the Sulu Basin floor is more comparable to the one of fastspreading ridges than the rough morphology expected for very slow accretion centers (Ballard and Van Andel, 1977). The Sulu Basin morphology is even smoother than the one of the South China Sea (Pautot et al., 1986) where a $2-\mathrm{cm} / \mathrm{yr}$ spreading rate was demonstrated on the basis of well-identified magnetic anomalies (Taylor and Hayes, 1983; Briais, 1989). Consequently, we urge caution on the interpretation of magnetic anomalies in the Sulu Basin.

The southeast Sulu Basin has a thin crust $(5.8 \mathrm{~km}$, Murauchi et al., 1973), and high heat-flow values (80-180 $\mathrm{mW} / \mathrm{m}^{2}$ ) were reported by Sclater et al. (1976) and Kudrass et al. (1987). Rocks dredged from small basement highs in this basin have a trace-element distribution comparable to transitional mid-oceanic-ridge basalts (Kudrass et al., 1987). At site $768,222 \mathrm{~m}$ of oceanic crust was penetrated from 1046 to $1268 \mathrm{mbsf}$. The sequence includes pillowed and brecciated vesicular olivine phyric basalt flows, olivine dolerite sills and microgabbros. The chemical data from Leg 124 suggest that the volcanic rocks may be transitional between mid-oceanic-ridge basalts (MORB) and island -arc tholeiites. The first sediments deposited on the basement consist of alternating dark-brown claystones and greenish gray tuffs, the contact being gradational between both lithologies. Rare broken radiolarians indicate an early Miocene age (Stichocorys wolffii Zone), but this determination remains tentative. The identification of magnetic reversal $5 \mathrm{E}$ in the overlying pyroclastics suggests a minimum age of $19 \mathrm{Ma}$ for the Sulu Sea basin floor.

The southeast Sulu Basin is presently subducting along the Sulu Trench. The deformation front which connects eastward with the Negros Trench is well identified north of Zamboanga Peninsula (Fig. 2) but is blanketed by a wide prograding apron in the west (Mascle and Biscarrat, 1978). The trench may 


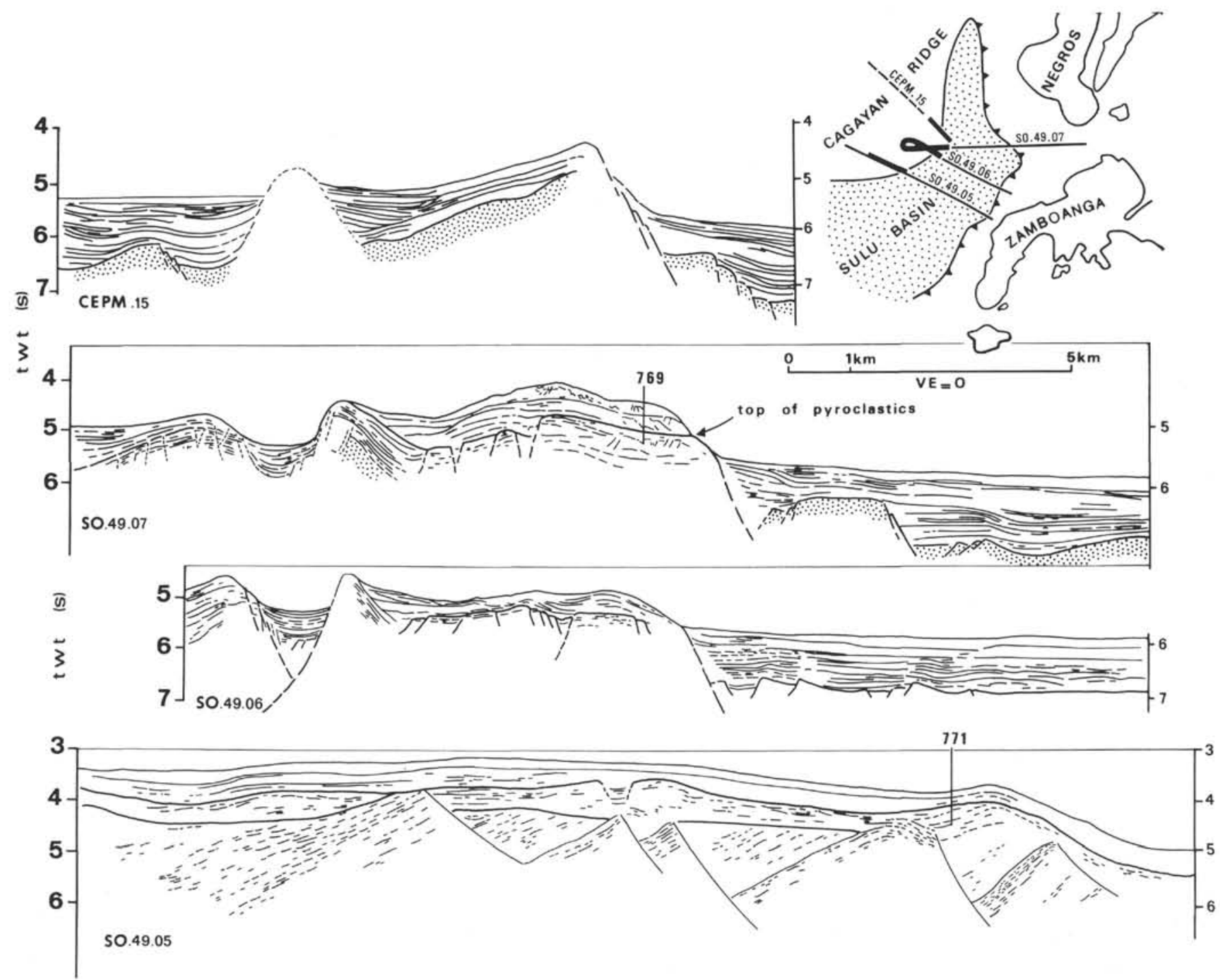

Figure 7. Line drawings of selected multichannel seismic profiles across the southeastern flank of the Cagayan Ridge. Location of drilling Sites 769 and 771 are shown.

enter central Sabah, but it may also connect by some transform faulting with the active North Borneo trench (Hinz et al., 1989). The Negros Trench shallows progressively northward before merging in southern Panay Island with imbricated Neogene volcanic-arc sequences (United Nations, 1984; Rangin et al., in press).

\section{The Sulu Ridge}

Arc volcanic activity along the Sulu archipelago is PlioPleistocene in age. However, older volcanic-arc sequences are known at both ends of the archipelago. On Zamboanga Peninsula the pre-Tertiary metamorphic basement is overlain directly by andesites, tuffs, and sediments with basal ages of Zone NN5 (16.2-14.4 Ma, C. Muller, written communication 1990). This volcanic arc can be traced northward in Panay (Valderrama Unit: Rangin et al., in press) where it was dated NN5 to NN9 (16.2-9 m.y.). For the Dent Peninsula in Sabah the same arc was dated radiometrically 13-11 Ma (Rangin et al., 1990a; Bellon and Rangin, this volume).

This volcanic episode was found at Site 768 , between 650 and 725 mbsf. Tuffs occur in three upward-fining sequences between 2.5 and $4.7 \mathrm{~m}$ thick. These sequences have sharp bases and show parallel layering in the lower part, grading up into thinly laminated coarse and fine tuffs. In the upper parts of the sequences the laminations are convolute or wavy, and dish-and-pillar structures provide evidence of water escape during deposition. These volcanics were redeposited by turbidity currents, but the abundance of angular glass shards indicates that the volcanic material was produced by coeval volcanic activity rather than by being eroded from older volcanic rocks. We think these volcanics may have originated in the Sulu arc because volcanic activity had already stopped on Cagayan Ridge. These tuffs were dated by nannofossils at Zone NN8 to the base of Zone NN9.

No major volcanic activity was recorded in the southeast Sulu Basin between 16.4 and $11 \mathrm{Ma}$ (Zones NN5 through NN8). Sparse biostratigraphic data for this interval (Rangin, Silver, Von Breymann, et al., 1990) indicate either a period of slow sedimentation or a possible hiatus in middle Miocene time, or both. The basin may have been protected from the Sulu arc at that time by a trench. 

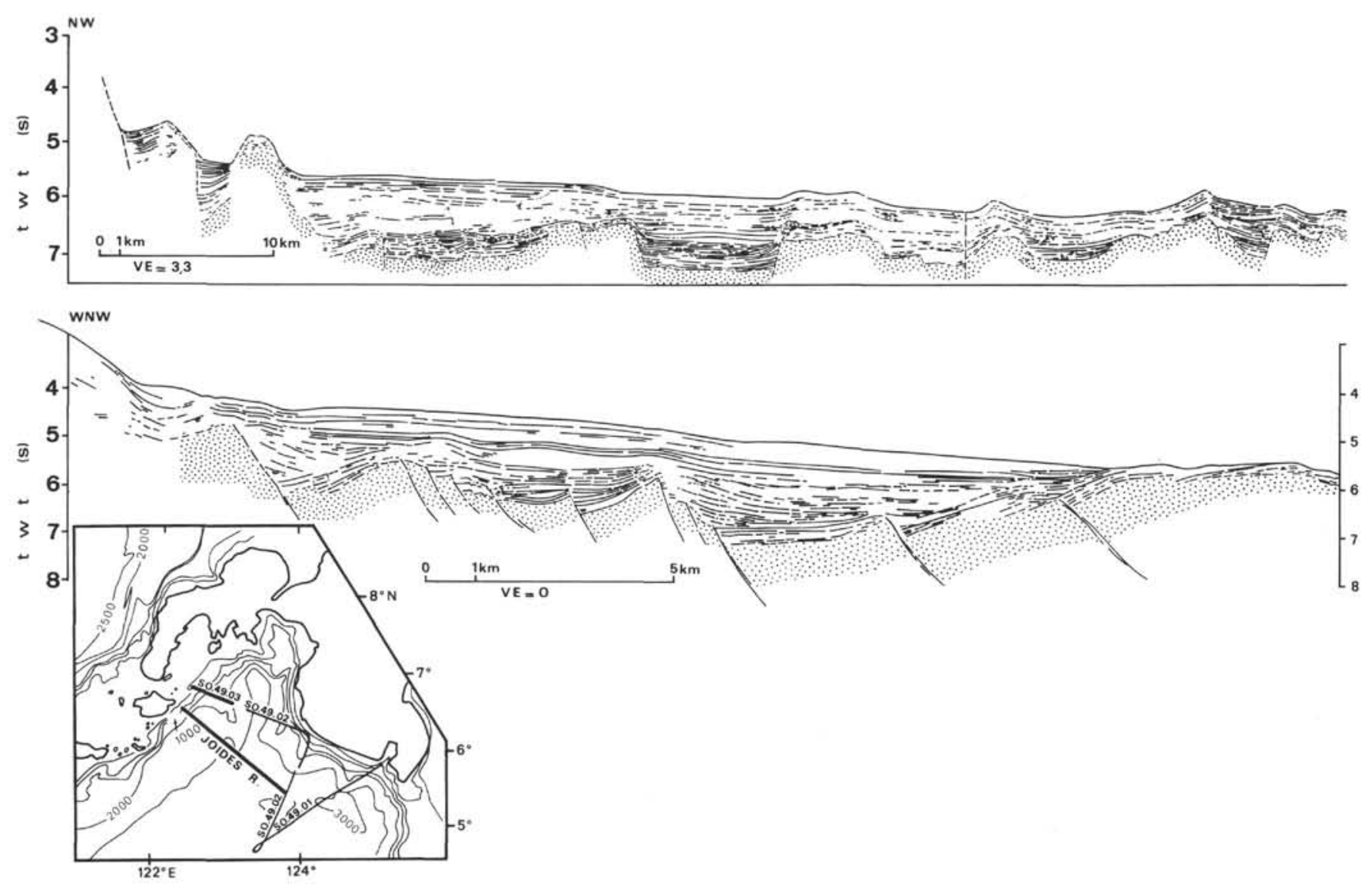

Figure 8. Multichannel seismic and single-channel seismic line drawings along the northeastern margin of the Celebes Sea.

\section{From Sulu Ridge to Celebes Basin}

The southern flank of the Sulu Archipelago is a relatively steep slope interpreted either as a normal-faulted passive margin or as a starved subduction zone. Single-channel seismic lines published by Hamilton (1979) do not clarify this ambiguity. Recent multichannel seismic (MCS) data shot south of Zamboanga by BGR, and one line collected during underway geophysics operations of Leg 124 on board JOIDES Resolution (Fig. 8), reveal the presence of south-facing tilted blocks. Field work recently conducted on the Zamboanga Peninsula, demonstrated similar tilted blocks. These results reveal the presence of a passive margin along the northern side of the Celebes Sea.

The morphology of the Celebes seafloor deduced from the bathymetry suggests it is composed of two sub-basins separated by a prominent northwest-trending ridge connecting northward with the Sulu Archipelago (Fig. 2). Sites 767 and 770 were drilled in the less sedimented northwest basin, which shows no clear magnetic anomalies. The drilled area is located on a broad northwest-trending gravity high, probably associated with flexure of the crust seaward of the Cotabato Trench.

Northeast-trending magnetic anomalies occur only within the southwest part of the Celebes Basin (Fig. 2, Weissel, 1980). Anomalies 18-20 have been identified by Weissel to indicate formation of that part of the basin in middle Eocene time and younging to the south. The drilled area is crossed by MCS profiles run by the BGR in 1987 and processed through migration (Hinz et al., 1988). Additional SCS profiles were collected by JOIDES Resolution during survey of the sites.
The trend of fault scarps of the ocean floor is not well constrained, but based on tentative correlation between line SO49-2 and the seismic line of the Joides resolution we map a - trend of N 63 E for the fabric of the oceanic crust (Rangin, Silver, von Breymann et al., 1990). This trend is compatible with the trend of the Sulu Ridge margin and the magnetic anomaly pattern found to the southwest (Weissel, 1980). The complete set of anomalies ( 18 to 20 ) could exist between the drill site and the Sulu margin. A sufficient area of abyssal plain extends southeast of Site 767 to allow the presence of the symmetric anomaly pattern (Fig. 2). Consequently, the drill sites may not be located far from the youngest position of spreading in the Celebes Basin.

Based on these data we consider that a passive margin exists between the Celebes Sea and the Sulu Ridge. This ridge was the closest volcanogenic source for Sites 767 and 770 . If our tentative reconstruction of the structural fabric of the basin is correct, drill sites are located on the northern side of the spreading ridge.

Basement of Site 770 was encountered $364 \mathrm{~m}$ shallower than basement at Site 767. The basement high drilled at Site 770 was interpreted as a major tilted block, as attested by the similarity in basement geochemistry and coeval ages for the oldest sediments at both Sites 767 and 770 .

At Site 767 the basal sediments are represented by brown claystone with the clay fraction averaging $60 \%$ to $65 \%$ smectite and $25 \%$ illite, and the remaining $10 \%$ to $15 \%$ comprising kaolinite and chlorite. A similar relative abundance of clay minerals is seen in modern pelagic clays of the equatorial western Pacific (Griffin et al., 1968). Smectite abundance 
(derived from alteration of volcanic products, mainly ashes) is less dominant in the red claystones than in the Neogene section where volcanic ashes are randomly distributed and often preserved. These claystones contain very low amounts of terrestrial organic matter (Bertrand et al., this volume) or even of continental minerals such as phyllosilicates (Nicot et al., this volume). This suggests the deposition of these brown claystones in an environment not far from a continent but protected from terrestrial and volcanogenic input.

The proximity of the Sulu Ridge could demonstrate that this arc was not active during the spreading history of the Celebes Sea. At Site 767, the core directly overlying basement contains intervals with abundant but poorly preserved radiolarians of late middle Eocene age. The assemblage closely resembles the type late middle Eocene assemblage of the Podocyrtis chalara Zone (Riedel and San Filippo, 1970) to the Podocyrtis goetheana Zone.

Basement was encountered at 786 mbsf at Site 767 and 422 mbsf at Site 770. Seven flow units were identified at Site 770. Basalt flows are intruded by two dolerite sills near the base of the section. The flows are pillow basalts, breccias, and veined and brecciated basalts. All samples analyzed are tholeiitic, and geochemistry indicates strong MORB affinity.

\section{Celebes Sea to North Arm of Sulawesi}

Along the northern margin of the north arm of Sulawesi seismic reflection lines show increasing width of the accretionary wedge toward the west (Silver et al., 1983). The timing of movement along this thrust zone is not well determined. Volcanic-arc activity is widespread along the north arm of Sulawesi, which is truncated at its western end by the Palu Fault (Fig. 2). This thrust belt behaves as if it were pinned on its eastern end. Volcanic activity decreases westward to the Manado area, where active volcanoes indicate ongoing subduction of the Molucca Sea. In the west, where the roots of the island arc are exposed, large granodiorites were dated early to early middle Miocene ( 15 to $18.8 \mathrm{Ma}$ : Ratman et al., 1976; Bellon et al., this volume) the probable time for unroofing and crystallization of plutons. These plutons intrude older volcanics dated at $22 \mathrm{Ma}$ (Bellon et al., this volume).

This old island arc is unconformably covered by a second phase of arc volcanism dated from 7 to $4 \mathrm{Ma}$. The younging magnetic anomalies toward the south in the Celebes Basin imply a minimum destruction of between 150 and $350 \mathrm{~km}$ of oceanic crust along this northern Sulawesi subduction zone, which has been supported by island-arc activity since $7 \mathrm{Ma}$. Older volcanism and plutonism can be interpreted as the subduction of the Molucca Sea (or the Tethys) before collision of this volcanic arc with the Sula block (Hamilton, 1979).

In the Celebes Basin no significant volcanic- arc activity is recorded in the basal brown pelagic mudstone deposited from middle Eocene to early Miocene time. Only a color change (brown-red at the base to green above) in these deep-sea sediments at Site 767 was observed at a point representing about $18.5 \mathrm{Ma}$. Despite this color change, the green claystone has a clay composition similar to the underlying pelagic brown claystone (Silver and Rangin, this volume). Consequently, the early stage of Cagayan volcanic activity is not recorded in the Celebes Sea by a change in clay mineralogy during the Paleogene.

The color change in these deep-sea sediments could represent an increase in sediment supply to the basin from the same source, which caused sediment to be buried rapidly enough to prevent significant oxidation by bottom water (Smith, this volume). The 18.5-Ma age represents approximately the time of arrival of the first quartz turbidites at Site 767. These turbidities older than the Cagayan-Palawan collision cannot have their source in Sabah, but are (coeval) with crystallization ages of granodiorites in the north arm of Sulawesi. These quartz-rich turbidites could have been provided by erosion of these granodiorites following uplift and collision of this arc with the Sula Platform. This fits well with the end of the first phase of volcanic activity dated at $22 \mathrm{Ma}$. The change in color of the deep-sea sediments at Site 767 around 18.5 Ma could be explained by an overflow of smectite-rich sediments in the basin provided by the erosion of the arc.

\section{CORRELATION OF NEOGENE SEDIMENTARY, MAGMATIC, AND TECTONIC EVENTS ACROSS THE CELEBES-SULU BLOCK}

Stratigraphic correlations across the Celebes-Sulu block allow us to differentiate key periods for its tectonic evolution. The main marker is the collision of the Cagayan Ridge (the northern boundary of the Celebes-Sulu block) with Eurasia (the rifted Palawan margin), which initiated the still- active process of the closing of the Celebes and Sulu marginal basins. We will deal first with the origin of the Sulu Basin before discussing the closing history of the Celebes and Sulu basins as it is recorded in the drill holes and the geology of their margins. The origin of the Celebes Sea is discussed in a companion paper (Silver and Rangin, this volume).

\section{Origin of the Sulu Basin}

A main problem concerning the tectonic evolution of this area deals with the opening of the Sulu Sea. Drilling at Site 768 indicated a minimum age of $19 \mathrm{Ma}$ for initiation of spreading in this basin. This age is coeval with volcanic- arc activity along the Cagayan arc, suggesting that the basin opened in a back-arc position. The highly volatile contents and the traceelement characteristics of this basement indicate an arcrelated origin (Rangin, Silver, von Breymann, et al., 1990).

The duration of Cagayan arc volcanic activity remains uncertain and appears to be limited to a short interval of time, 22 to $15 \mathrm{Ma}$, or less. Traces of arc volcanic activity occur in the basal $43 \mathrm{~m}$ above basement at Sulu Basin Site 768. There, thin beds of fine tuffs with thick to thin planar laminations are interbedded with dark-brown hemipelagic claystone. Consequently, this basin probably opened in a back-arc setting. However, no volcanic-arc sequences older than Zone NN5 occur in the Zamboanga Peninsula, making the Sulu Ridge an unlikely candidate as a remnant volcanic arc for Cagayan Ridge. Additionally, only thin layers of volcanic-arc material were found interbedded with the basalts of the basement at Site 768. Much larger amounts of volcaniclastic material are found interbedded with basalts in intra-arc marginal basins such as the Ogasawara-Bonin arc (Taylor, Fujioka et al., 1990).

Poor constraints on the age of the oldest sediments at Site 768 , and their slow sedimentation rate, suggest that the basin could have opened before the Cagayan Ridge volcanic activity was initiated. This alternative hypothesis implies an origin for the Southeast Sulu Basin analogous to that of the South China Sea, independent of back-arc spreading processes. However the arc tholeiitic signature of the southeast Sulu Basin crust and the possible erosion of the remnant volcanic-arc sequences in the Zamboanga Peninsula favor the first hypothesis.

\section{Cagayan-Reed Bank Collision and Closing of the Celebes-Sulu Basins}

Once the Celebes-Sulu block had docked and amalgamated to the rifted margin of China (Palawan-Reed Bank) 15 $\mathrm{Ma}$, the basins began to subduct along their southern and eastern margins. New trenches were created, such as the 


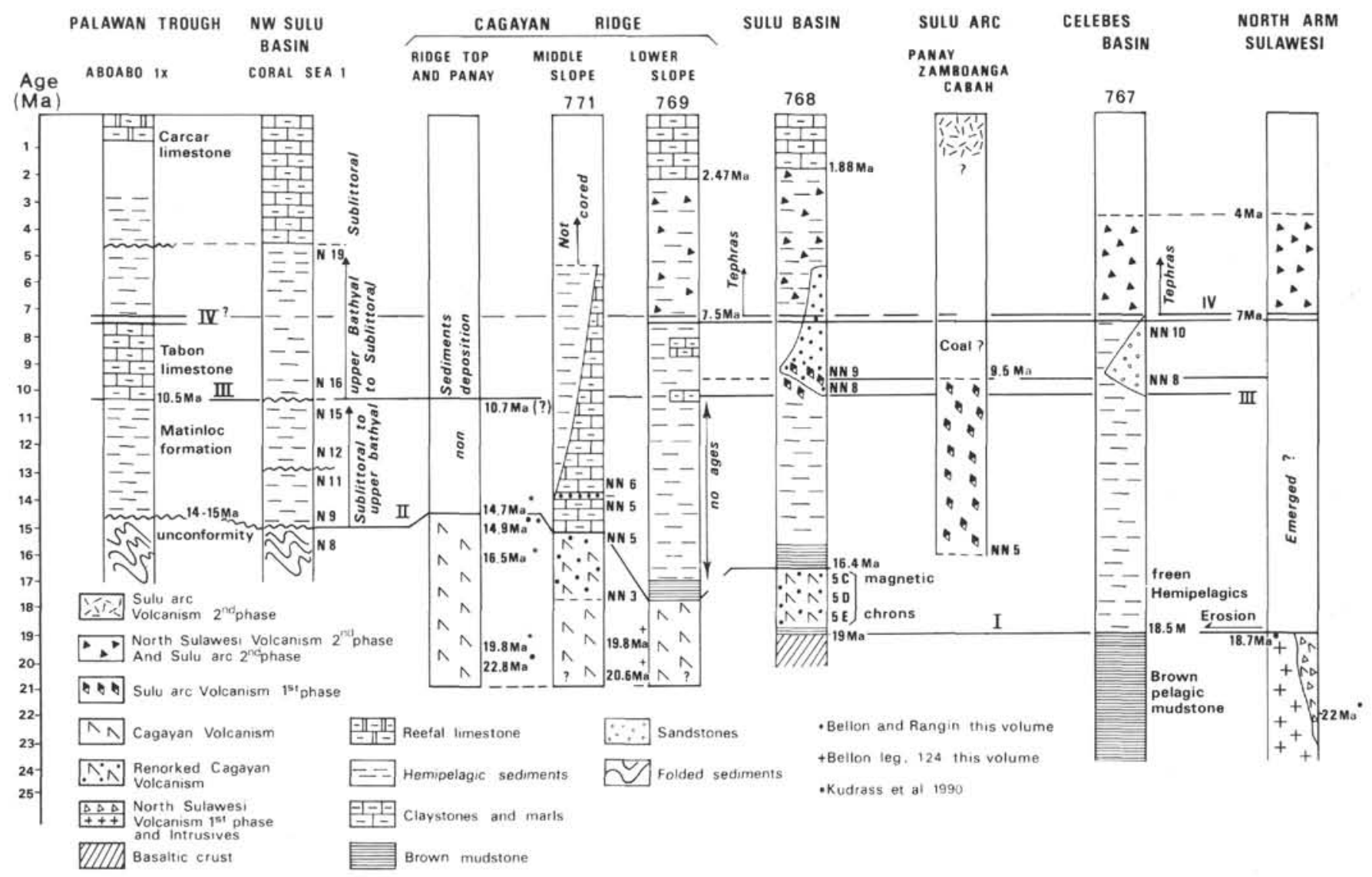

Figure 9. Correlation of chronostratigraphic logs across the Celebes-Sulu block. I, erosion of the north Sulawesi arc; II, Cagayan arc-Reed Bank collision; III, collision of the Philippine Mobile Belt with Cagayan Ridge; IV, incipient subduction along the north Sulawesi Trench.

Sulu-Negros Trench along the southeast Sulu Basin and the north Sulawesi/Cotabato Trenches for the Celebes. The Negros and Cotabato trenches are related to the convergence of the Philippine Mobile Belt and the Sulu and Celebes basins. However, the North Sulawesi Trench is a consequence of the northward motion of the Banda block. Incipient subduction along these newly born trenches can be studied by comparing magmatic activity on land with tephrochronology in the basins (Pubellier et al., this volume). These new trenches have modified the distribution of clastics in the basins, either interrupting or channeling the clastic material from the surrounding source areas.

The collision of Cagayan Ridge with the rifted margin of China is recorded by cessation of volcanism along Cagayan Ridge and by arrival of a flood of clastics into the Northwest Sulu Basin. Cessation of volcanism on Cagayan Ridge was determined by correlating existing data such as dredging on the ridge (Kudrass et al., 1990), on-land geology in Panay, and drilling at Sites 767, 768, 769, 770, and 771 (Fig. 9). Volcanic activity decreased rapidly after $17.8 \mathrm{Ma}$ (top of Zone NN3) at Site 771 , where sediments are intercalated with pyroclastics. Activity ceased about $14 \mathrm{Ma}$ high on the ridge (Kudrass et al., 1990), $15 \mathrm{Ma}$ at Site 771, and 17.5 Ma at Site 769 (Rangin, Silver, von Breymann et al., 1990). The thick pyroclastics drilled at Site 768 could not have come from the Sulu Ridge because volcanism did not begin in Zamboanga until Zone NN5 time. The 16.4-Ma age for the end of deposition of these pyroclastics at Site 768 is constrained by paleomagnetism and biostratigraphy. Consequently, it is most probable that volcanic activity stopped along the ridge approximately $16 \mathrm{Ma}$.
This timing fits well with the $15-\mathrm{Ma}$ age for cessation of deformation in the Northwest Sulu Basin, where deformed sediments are covered unconformably by upper bathyal to sublittoral, weakly deformed clastic sediments (Fig. 9). Therefore, the collision lasted only 1.5 to $2 \mathrm{~m} . \mathrm{y}$.

This collision and rapidly decreasing arc magmatism along Cagayan Ridge were followed immediately by initiation of volcanic activity along the Sulu Ridge, ranging in age from 16 to $9 \mathrm{Ma}$. This timing is documented by middle Miocene volcanism in the Zamboanga Peninsula (16.2-14.4 Ma) and in southern Sabah (16.5-9.5 Ma). We think the Southeast Sulu Basin was isolated from the volcanic turbidites of the Sulu arc by the active Sulu Trench. This is supported by the slow sedimentation rate at Site 768 between 16 and $11 \mathrm{Ma}$.

Only the latest part of this volcanic activity was recorded in the southeast Sulu Basin at about $10 \mathrm{Ma}$ by deposition of fresh volcaniclastic turbidites. Arrival of this material at Site 764 around $10 \mathrm{Ma}$ is coeval with collision of the Philippine arc with Cagayan Ridge at Panay Island (Rangin, 1989; Rangin et al., in press). It is also the time of cessation of volcanism and intense thrusting at Sabah (Rangin et al., 1990).

The age of initial deposition of quartz-rich turbidites in the Sulu Basin is poorly constrained. In the Celebes Sea the initiation of this influx falls within the unfossiliferous lower (?) to middle Miocene section. At Site 768 the continuing deposition of brown pelagic muds in the Sulu Sea above the pyroclastics indicates that this basin was probably protected from detrital arrival when the Cagayan arc ceased activity due to collision. We infer that the collision initiated the infilling of the northwest Sulu Basin before clastic sediments reached the 
Southwest Sulu Basin. On Cagayan Ridge, where dilution of fossils due to terrigenous influx is low (Site 771), the first fine-grained turbidites were deposited at a time approximating the boundary between Zones NN5 and NN6 (14.4 Ma).

The peak in turbidite sedimentation in the late middle Miocene (Zone NN9, 9.5 Ma) is coeval all across the Sulu and Celebes basins. This peak coincides with cessation of volcanism along the Sulu arc at Sabah (Fig. 9). It is also the time of collision of Cagayan Ridge with the Philippine arc at Panay (dated by cessation of volcanism). The most evident source for massive supply of quartz-rich clastics was Sabah, where the Crocker Formation has been exposed since early middle Miocene time. The apex of this clastic sedimentation in both basins corresponds with deposition of the Sebahat Formation of southern Sabah, a molasse deposit dated at Zone NN8 (Rangin et al., 1990a). The numerous coal fragments found in these turbidities at Sites 767 and 768 have sources either in the coal-rich deposits of the middle Miocene circular basins of Sabah or in the coal deposits of the Lumbog Formation of Zamboanga (Antonio, 1972).

This massive turbidite event may have been enhanced by a fall of global sea level at that time (Haq et al., 1988), facilitating the rapid exposure and erosion of the already deformed Crocker sediments on Sabah. This event is also documented at Site 769 by the presence of carbonates (nannofossil marls) and by deposition of the Tabon Limestone in the Palawan trough. In the northwest Sulu Basin a transition from an upper bathyal to a sublittoral environment also attests to this sea-level change. Here the unconformity described by Beddoes (1976) in the Coral Sea 1 well can be extended to the top of layer B (Fig. 6A). Consequently, the middle to late Miocene boundary is an important period for the Celebes-Sulu block, marked by deformation and significant sea-level rise.

Clastic arrival suddenly stopped around $8.5 \mathrm{Ma}$ in the Celebes Basin. This cessation corresponds to deposition of abundant tephras. This explosive volcanic-arc marker was also found at Site 769 around $7.5 \mathrm{Ma}$ (Pubellier et al., this volume). This age fits quite well with the second phase of volcanism along the north arm of Sulawesi (Fig. 9). At Site 768 , terrigenous input was active up to $5.5 \mathrm{Ma}$, masking by dilution the incipient arrival of the tephras. We interpret this tephra event as renewal of volcanic activity along the north arm of Sulawesi, due to newly created subduction along the north Sulawesi Trench. The coeval waning of the terrigenous supply to the Celebes Basin can be explained by channeling of the clastic sediments from Borneo along this new trench. Thus a minimum age for the tectonic activity along that trench is $7.5 \mathrm{Ma}$.

After onset of collision at Palawan, compression within the Celebes-Sulu block was first accommodated along the Sulu Trench, inducing incipient closing of the basins and subduction of the Sulu Basin. This event was followed by a southward jump to the north arm of Sulawesi, initiating subduction of the Celebes Basin.

\section{A MODEL FOR THE NEOGENE EVOLUTION OF THE CELEBES-SULU BLOCK}

We propose a simple scenario for the Neogene evolution of the Celebes-Sulu block (Fig. 10). At the end of early Miocene time the southern margin of the Celebes-Sulu block collided with the Banda block in central Sulawesi. This collision induced rapid subduction and closing of the proto-South China Sea along the northern margin of the Celebes-Sulu block, and the Cagayan volcanic arc was rapidly built. Ages older than 22 Ma cannot be demonstrated for this subduction, suggesting that the proto-South China Sea was subducted in a few million years (Rangin et al., 1990b). This timing indicates that the proto- South China Sea was smaller and narrower than originally proposed by Taylor and Hayes (1983).

Two hypotheses for the origin of the southeastern Sulu Basin are presented in Figure 10. The first favors a back-arc origin (A). The second scenario (B) suggests that the Sulu Sea Basin predated the Cagayan and opened along the Eurasian margin, analogous with the South China Sea. The first hypothesis is supported by the back-arc geochemical signature of the Southwestern Sulu Basin crust, and the second by absence of remnant volcanic-arc sequences along the Sulu Ridge.

The end of the proto-South China Sea subduction and incipient collision of the Cagayan arc with the rifted Palawan fragment of China induced a large outpouring of pyroclastics, covering the whole Cagayan Ridge. These volcanics were rapidly remobilized as turbidites and deposited in the southeast Sulu Basin. This explosive volcanism could be explained by a large volume of interstitial water in the proto-South China Sea sediments involved in the Palawan subduction zone. Volcanism along Cagayan Ridge decreased rapidly and stopped completely in early middle Miocene time.

The cessation of volcanism can be easily correlated with cessation of deformation in the northwest Sulu Basin and Palawan Trench.

1. In middle Miocene time, deformation affected the interior of the block. The Sulu Sea subducted southward along the Sulu arc from 15 to $10 \mathrm{Ma}$, and the northwest Sulu Basin trapped the clastics resulting from the Cagayan-Reed Bank collision.

2. In early late Miocene time, collision of the Sulu arc with Eurasia at Sabah and Panay induced massive quartz turbidite deposition in both basins. This collision was enhanced by a sea-level drop at that time, facilitating erosion of terranes surrounding the basins.

3 . In the middle late Miocene, major renewal of volcanicarc activity in north Sulawesi is interpreted as the incipient southward subduction of the Celebes Basin.

Correlations of Leg 124 drilling data with on-land geology illustrate how the Celebes-Sulu block was progressively deformed, first along its margin, then in the interior. Subsequent and progressive deformation toward the south of the interior of this block mainly has been accommodated by short-lived subduction zones. Deciphering the closing history of these marginal basins provides basic information for the incipient stage of mountain building. The closing of these basins predates the expected collision between Eurasia and Australia and sheds some light on the preliminary stages of large continent collision, such as India-Eurasia and Africa-Europe.

\section{ACKNOWLEDGMENTS}

We are indebted to $\mathrm{K}$. Hinz for providing us with migrated seismic profiles, and to D. E. Karig and J. M. Parsons for critical reviews of this manuscript. Silver acknowledges the United States Science Advisory Committee and the French CNRS for support of data analysis and manuscript preparation. Rangin acknowledges INSU and CNRS through its "Oceanoscope" committee for support of this work.

\section{REFERENCES}

Antonio, L. R., 1972. Geology and Mineral Resources of East Central Zamboanga Peninsula, Mindanao, Philippines. Phil. Bur. Min. Rep.

Audley-Charles, M. G., 1968. The geology of the Portugese Timor. Mem. Geol. Soc. London, 4:1-76. 
Ballard, R. D., and Van Andel, T. H., 1977. Morphology and Tectonics of the inner rift valley at latitude $36^{\circ} \times 50^{\prime} \mathrm{N}$ on the Mid Atlantic Ridge. Geol. Soc. Am. Bull., 88:507-530.

Beddoes, L. R., 1976. The Balabac Sub-Basin, Southwestern Sulu Sea, Philippines. Seapex Program, Offshore South East Asia Conf., 15:22.

Berggren, W. A., Kent, D. V., Flynn, J. J., and Van Couvering, J. A., 1985. Cenozoic geochronology. Geol. Soc. Am. Bull., 96:14071418 .

Briais, A., 1989. Cinématique d'ouverture de la Mer de Chine du Sud (Nanhai): implications pour la tectonique Tertiaire de l'Asie [These]. Univ. Paris VI

Fricaud, L., 1984. Etude géologique et structurale de la marge ouest Palawan (mer de Chine méridionale) [Thèse Doctorat]. Univ. Paris-Sud, Orsay.

Griffin, J. J., Windom, H., and Goldberg, E. D., 1968. The distribution of clay minerals in the World Ocean. Deep-Sea Res. Oceanogr. Abstr., 15:433-459.

Hamilton, W., 1979. Tectonics of the Indonesian region. Geol. Surv. Prof. Paper U.S., 1078:345.

Haq, B. U., Hardenbol, J., and Vail, P. R., 1988. Mesozoic and Cenozoic chronostratigraphy and cycles of sea-level change. In Wilgus, C., et al., (Eds.), Sea-Level Change - An Integrated Approach. Soc. Econ. Paleontol. Mineral. Spec. Publ., 42:71-108.

Hinz, K., and Block, H. U., 1985. Geology of the Dangerous Grounds, South China Sea, and the Continental off Southwest Palawan: results of Sonne Cruise S0-23 and S0-27. Energy, 10:297-315.

Hinz, K., and Block, M., 1990. Summary of geophysical data from the Sulu and Celebes Seas. In Rangin, C., Silver, E. A., et al., Proc. $O D P$, Init. Repts., 124: College Station, TX (Ocean Drilling Program), 87-92.

Hinz, K., Kemper, E.H.K., and Schluter, H. U., 1985. The Southern Palawan-Balabac area: an accreted or non-accreted terrane. Proc. 3rd Asian Council on Petrol. (ASCOPE), Conf. Exhib., 1985, Kuala Lumpur, Malaysia, 2:48-60.

Hinz, K., Fritsch, J., Kempter, E.H.K., Manaf Mohammad, A., Meyer, J., Mohamed D., Vosberg, H., Weber, J., 1989. Thrust Tectonics along the North-Western Continental Margin of SabahBorneo. Geol. Rundsch., 73:705-730.

Holloway, N. H., 1982. The stratigraphy and tectonic relationship of Reed Bank, North Palawan, and Mindoro to the Asian Mainland and its significance in the evolution of the South China Sea. $A A P G$ Bull., 66:1357-1383.

Jolivet, L., Huchon, P., and Rangin, C., 1989. Tectonic setting of Western Pacific marginal basins. Tectonophysics, 160:23-47.

Kudrass, H. R., Heidicke, M., Cepek, P., Kreuser, H., and Muller, P., 1986. Mesozoic and Cenozoic rocks dredged from the South China Sea (Reed Bank area) and Sulu Sea, and their significance for plate tectonic reconstructions. Mar. Pet. Geol., 3:19-30.

Kudrass, H. R., Muller, P., Kreuzer, H., and Weiss, W., 1990. Volcanic rocks and tertiary carbonates dredged from the Cagayan Ridge and the Southwest Sulu Sea, Philippines. In Rangin, C., Silver, E. A., et al., Proc. ODP, Init. Repts., 124: College Station, TX (Ocean Drilling Program), 93-100.

Kundig, E., 1956. Geology and ophiolite problems of east Celebes. Verh. K. Ned. Geol. Mijnbouwkd. Genoot., 16:210-235.

Letouzey, J., Sage, L., and Müller, C., 1988. Geological and Structural Maps of Eastern Asia. Introductory Notes. AAPG.

Marchadier, Y., and Rangin, C., 1990. Polyphase Tectonics at the Southern Tip of the Manila Trench, Mindoro Tablas Islands Philippines. Tectonophysics, 183:273-288.

Mascle, A., and Biscarrat, P. A., 1978. The Sulu Sea: a marginal basin in Southeast Asia. In Watkins, J. S., Montadert, L., and Dickerson, P. W. (Eds.), Geological and Geophysical Investigations of the Continental Margins: AAPG Mem., 29:373-381.

Mitchell, A.H.G., Hernandez, F., and Dela Cruz, A. P., 1986. Cenozoic evolution of the Philippine Archipelago. J. Southeast Asian Earth Sci., 1:3-22.

Murauchi, S., Ludwig, W. J., Den, N., Notta, H., Asanuma, T., Yoshii, T., Kubotera, A., and Hagiwara, K., 1973. Structure of the Sulu Sea and the Celebes Sea. J. Geophys. Res., 78:3437-3447.

Pautot, G., Rangin, C., Briais, A., Tapponnier, P., Beuzart, P., Lericolais, G., Mathieu, X., Wu, J., Li, H., Lu, Y., Zhao, 1986.
Spreading direction in the Central South China Sea. Nature, 321:150-154.

Rangin, C., 1989. The Sulu Sea, a back arc basin setting within a Neogene collision zone. Tectonophysics, 161:119-141.

Rangin, C., Bellon, H., Benard, F., Letouzey, J., Muller, C., and Tahir, S., 1990a. Neogene arc continent collision in Sabah: Northern Borneo (Malaysia). Tectonophysics, 183:305-320.

Rangin, C., Jolivet, L., Pubellier, M., and Tethys Pacific Working Group, 1990b. A simple model for the tectonic evolution of Southeast Asia and Indonesia regions for the past $43 \mathrm{Ma}$. Bull. Soc. Gèol. Fr., 887-905.

Rangin, C., Pubellier, M., 1990. Subduction and accretion of oceanic fragments along the Eurasian margin: southern Japan-Philippine region. Some constrains for continental growth. In Aubouin, J., and Bourgois, J. (Eds.), Tectonics of Circum Pacific Continental Margins, (V.S.P International Publ.), 139-144.

Rangin, C., Silver, E., and Leg 124 Scientific Party, 1989. Forages dans les bassins marginaux du SE asiatique: résultats préliminaires du Leg 124 (Ocean Drilling Program). C. R. Acad. Sci. Ser. 2, 309:1333-1339.

Rangin, C., Silver, E. A., von Breymann, M. T., et al., 1990. Proc. ODP, Init. Repts., 124: College Station, TX (Ocean Drilling Program).

Rangin, C., Stephan, J. F., Butterlin, J., Bellon, H., Müller, C., Chorowicz, J., Baladad, D., in press. Collision nèogène d'arcs volcaniques dans le centre des Philippines. Stratigraphie et structure de la chane d'Antique le de Panay. Bull. Soc. Gèol. Fr.

Rangin, C., Stephan, J. F., and Müller, C., 1985. Middle Oligocene oceanic crust of South China Sea jammed into Mindoro collision zone (Philippines). Geology, 13:425-428.

Raschka, H., Nacario, E., Rammlmair, D., Samonte, C., and Steiner, L., 1985. Geology of the ophiolite of central Palawan Island, Philippines. Offioliti, 10:375-390.

Ratman, N., 1976. Geological map of the Tolitoli Quadrangle, North Sulawesi, 1:250,000. Geol. Surv. Indonesia Min. Mines.

Riedel, W. R., and Sanfilippo, A., 1970. Radiolaria, Leg 4, Deep Sea Drilling Project. In Bader, R. G., Gerard, R. D., et al., Init. Repts. DSDP, 4: Washington (U.S. Govt. Printing Office), 503-575.

Sarewitz, D. R., and Karig, D. E., 1986. Processes of allochtonous terrane evolution, Mindoro Island, Philippines. Tectonics, 5:525552.

Sclater, J. G., Karig, D. E., Lawver, L. A., and Louden, K., 1976. Heat flow, depth, and crustal thickness of the marginal basins of the south Philippine Sea. J. Geophys. Res., 81:309-318.

Silver, E. A., McCaffrey, R., Joyodiwyrio, Y., and Stevens, S., 1983a. Ophiolite Emplacement by Collision between the Sula Platform and the Sulawesi Island Arc, Indonesia. J. Geophys. Res., 88:9419-9435.

Silver, E. A., McCaffrey, R., Smith, R. B., 1983b. Collision, rotation, and the initiation of subduction in the evolution of Sulawesi, Indonesia. J. Geophys. Res., 88:9407-9418.

Taylor, B., Fujioka, K., et al., 1990. Proc. ODP, Init. Repts., 126: College Station, TX (Ocean Drilling Program).

Taylor, B., and Hayes, D. E., 1983. Origin and history of the South China Sea Basin. In Hayes, D. E. (Ed.), Tectonic and Geologic Evolution of Southeast Asian Seas and Islands (Pt. 2): Am. Geophys. Union Monogr., 27:23-56.

United Nations Development Program and the Philippine Bureau of Mines and Geosciences, 1983. Cenozoic geological evolution of Southwestern Panay and adjacent areas. Philippine Geologist, Oct.-Dec.:16-36.

Weissel, J. K., 1980. Evidence for Eocene oceanic crust in the Celebes Basin. In Hayes, D. E. (Ed.), The Tectonic and Geologic Evolution of Southeast Asian Seas and Islands. Am. Geophys. Union, Geophys. Monogr. Ser., 23:37-47.

Wolfart, R., Cepek, P., Gramann, F., and Porth, H., 1986. Stratigraphy of Palawan island, Philippines. Newsl. Stratigr., 15:19-48.

Date of initial receipt: 26 June 1990

Date of acceptance: 13 December 1990

MS 124B-122 

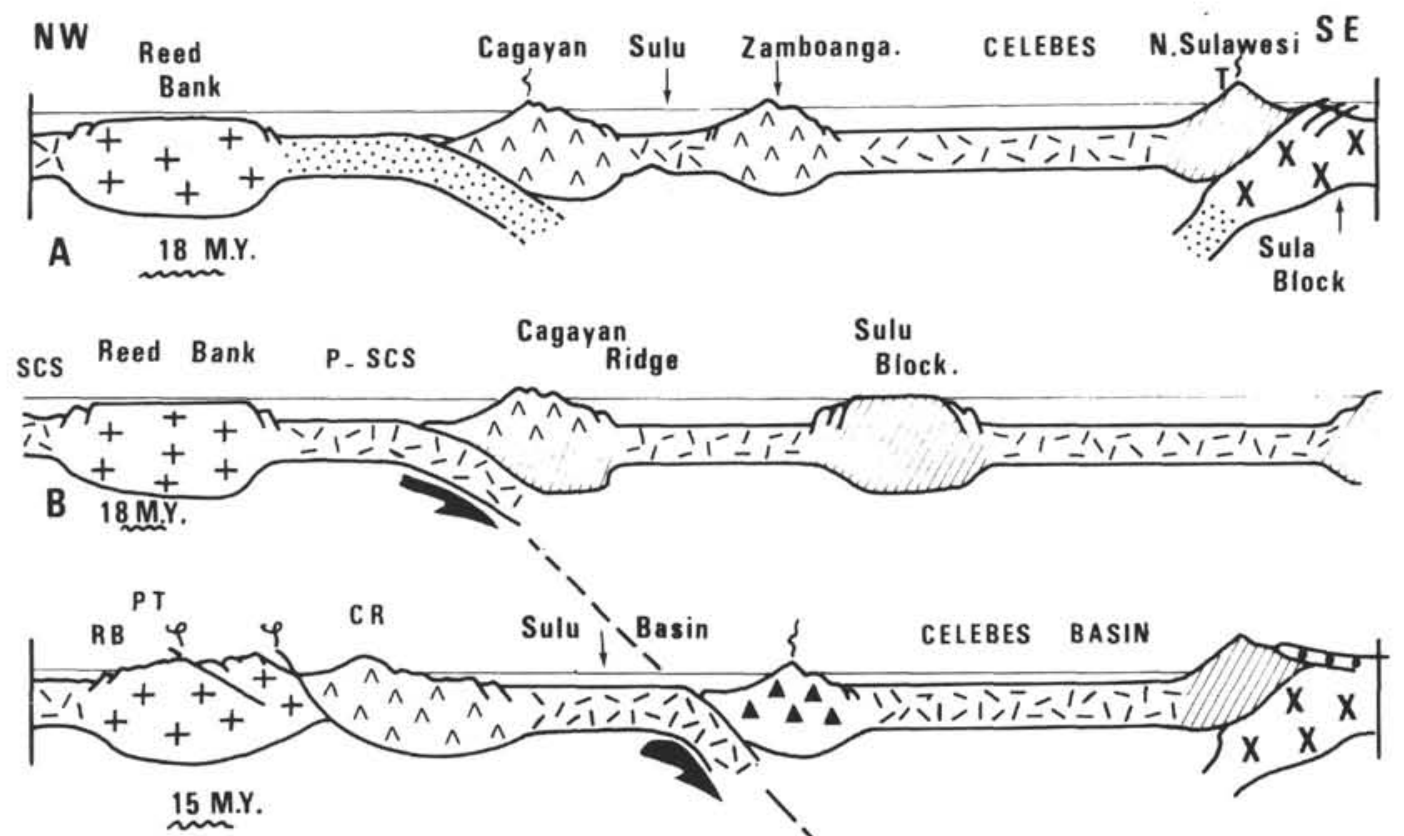

15 M.Y.

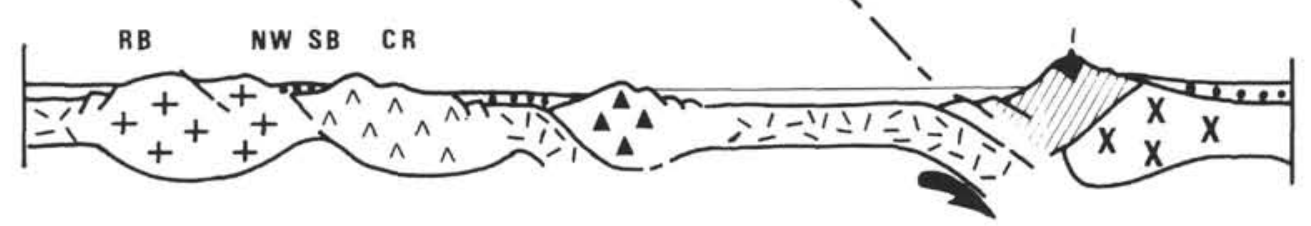

8 M.Y.

Figure 10. Interpretive diagram for the evolution of the Celebes-Sulu block during the Neogene. Two distinct hypotheses are proposed for the origin of the Sulu Basin A and $\mathbf{B}$; see explanation in text). 